Tropical Journal of Pharmaceutical Research, March 2007; 6 (1): 661-670

(C) Pharmacotherapy Group Faculty of Pharmacy, University of Benin Benin City, Nigeria.

All rights reserved.

Research Article

Available online at http://www.tjpr.org

\title{
Evaluation of Pharmaceutical and Microbial Qualities of Some Herbal Medicinal Products in South Western Nigeria
}

\author{
Adenike Okunlola, Babatunde A. Adewoyin and Oluwatoyin A. \\ Odeku* \\ Department of Pharmaceutics \& Industrial Pharmacy, Faculty of Pharmacy, University of Ibadan, Ibadan, Nigeria.
}

\begin{abstract}
Purpose: The aim of the present study was to investigate the pharmaceutical and microbial qualities of 21 different (of various dosage forms) Herbal Medicinal Products (HMPs) sourced from some traditional medicine sales outlets and retail pharmacy outlets in south western Nigeria.

Method: The pharmaceutical qualities evaluated include tablet crushing strength, friability, disintegration time; density of the solutions and suspensions; particle size and angle of repose of the powders. Phytochemical tests were carried out to assess the class of compounds present in the formulations and the microbial quality of the products was also evaluated.

Results: The results show that twelve (57.1\%) of the products had their manufacturing and expiry dates stated, nine (42.9\%) products have been registered by NAFDAC and ten (47.6\%) did not have their content stated but had their therapeutic claims indicated on the container. The tablet formulation (Product A) showed acceptable crushing strength and friability but failed the test for disintegration time. The angle of repose of the powder dosage forms were considerably high showing that the powders were highly cohesive and not free flowing. The microbial load of the products varied considerably. Ten (47.6\%) of the samples were contaminated by E. coli, seven (33\%) were contaminated by Salmonella, fifteen (71.4\%) were contaminated by Staphylococcus aureus and twelve (57.1\%) were contaminated by fungi.
\end{abstract}

Conclusion: There is need for constant monitoring and control of the standards of herbal medicines available in the Nigerian market.

Keywords: Herbal medicinal products, microbial quality, pharmaceutical quality.

*Correspondence: Email: pejuodeku@yahoo.comt Tel 2348033235828; 23428106403 


\section{INTRODUCTION}

Herbal medicine, a form of complimentary and alternative medicine, is becoming increasingly popular in both developing and developed countries $^{1}$. A World Health Organization (WHO) survey indicates that about $70-80 \%$ of the world population particularly in the developing countries rely on non-conventional medicines mainly of herbal sources in their primary healthcare ${ }^{2,3}$. WHO has described traditional medicine as one of the surest means to achieve total health care coverage of the world's population. In pursuance of its goal of providing accessible and culturally acceptable health care for the global population, WHO has encouraged the rational use of traditional plant based medicines by member states and has developed technical guidelines for the assessment of herbal medicine ${ }^{3,4}$.

In Nigeria, there appears to be an overwhelming increase in the public awareness and usage of herbal medicinal products in the treatment and/or prevention of diseases. This may not be unconnected to the active mass media advertisement embarked upon by the producers and marketers of the herbal medicinal products (HMPs) who have taken the advantage of the relatively high cost of the conventional pharmaceutical dosage forms, inaccessibility of the orthodox medical services to a vast majority of people particularly in the rural areas and the reservations by the public due to the prevalence of fake, substandard or counterfeit drugs in the market. These have placed the HMPs as a ready alternative to conventional dosage forms in the treatment of diseases. With this increased usage, the safety, efficacy and quality of these medicines have been an important concern for health authorities and health professionals. Although herbal remedies are often perceived as being natural and therefore safe, they are not free from adverse effects which may be due to factors such as adulteration, substitution, contamination, misidentification, lack of standardization, incorrect preparation and/or dosage, inappropriate labeling and/or advertisement ${ }^{5}$. In contrast to chemically defined medicinal products, the biopharmaceutical quality and behavior of HMPs are often not well documented $^{6}$. The WHO Good Manufacturing Practice Guidelines have provided technical guidelines to national regulatory authorities, scientific organizations, and manufacturers to undertake an assessment of the documentation/submission/dossiers in respect of herbal medicinal products. In Nigeria, the National Agency for Food Drug Administration and Control (NAFDAC) is responsible for drug administration and control of the quality of medicinal products including HMPs generally available in the market.

In an attempt to enhance the acceptability of the HMPs by consumers, many of the products have been formulated into conventional modern dosage forms such as tablets, capsules, suspensions, solutions and powders. With the prevalence in the Nigerian market of these products, it would be of great interest to evaluate the pharmaceutical qualities of these HMPs, irrespective of the medicinal content and therapeutic claims. Thus in the present study, the pharmaceutical and microbial qualities of 21 different brands of Herbal Medicinal Products (HMPs) sourced from various traditional medicine sales outlets and retail pharmacy outlets in south western Nigeria have been evaluated. Phytochemical tests were done to assess the class of compounds in the formulations and the microbial content was also evaluated.

\section{Materials and methods Materials}

The following materials were used: Nutrient broth, Nutrient agar, MacConkey agar, Salt nutrient agar, Cetrimide Nutrient agar, Sabauraud dextrose agar were all obtained from Oxoid (Oxoid Products, Basingstoke, UK). Twenty one (21) different Herbal Medicinal Products (HMPs) were sourced from various traditional medicine sales outlets and retail pharmacy outlets in south western Nigeria. The type of dosage form, manufacture and expiry dates and the therapeutic indications are presented in Table 1. 
Table1: Product code, Dosage form, Content, NAFDAC registration, Country of Origin, Manufacture and Expiry dates of 21 brands of HMPs from the Nigerian Market

\begin{tabular}{|c|c|c|c|c|c|c|c|}
\hline $\begin{array}{l}\text { Product } \\
\text { code }\end{array}$ & $\begin{array}{l}\text { Dosage } \\
\text { form }\end{array}$ & $\begin{array}{l}\text { Date of } \\
\text { manufacture }\end{array}$ & $\begin{array}{l}\text { Expiry } \\
\text { Date }\end{array}$ & $\begin{array}{l}\text { Country of } \\
\text { Manu. }\end{array}$ & $\begin{array}{l}\text { NAFDAC } \\
\text { Reg. }\end{array}$ & Contents & $\begin{array}{l}\text { Therapeutic } \\
\text { claim }\end{array}$ \\
\hline $\mathrm{A}$ & Tablet & Aug 2003 & $\begin{array}{l}\text { Aug } \\
2007\end{array}$ & US & No & $\begin{array}{l}\text { Gingko biloba } \\
\text { extract, Ganoderma } \\
\text { lucidum, } \\
\text { Schisandra } \\
\text { chinensis }\end{array}$ & $\begin{array}{l}\text { Brain fatigue, } \\
\text { improvement } \\
\text { of thought } \\
\text { process. }\end{array}$ \\
\hline B & Capsule & - & - & Nigeria & No & - & $\begin{array}{l}\text { Hypertension, } \\
\text { Diabetes, } \\
\text { Yellow fever }\end{array}$ \\
\hline $\mathrm{C}$ & Capsule & Jul 2004 & $\begin{array}{l}\text { Jun } \\
2007\end{array}$ & Nigeria & No & $\begin{array}{l}\text { Strophanthus } \\
\text { sarmentosus } 75 \% \text {, } \\
\text { Pyrenancantha } 25 \%\end{array}$ & $\begin{array}{l}\text { Chronic fever, } \\
\text { Cough }\end{array}$ \\
\hline $\mathrm{D}$ & Capsule & Oct 2002 & $\begin{array}{l}\text { Oct } \\
2005\end{array}$ & Nigeria & Yes & $\begin{array}{l}\text { Hibiscus sabdariffa } \\
\text { 80mg, } \\
\text { Sorgum bicolor } \\
60 \mathrm{mg}, \\
\text { Gongronema } \\
\text { latifolium 35mg }\end{array}$ & $\begin{array}{l}\text { Energizer, } \\
\text { Immune } \\
\text { booster, } \\
\text { Blood } \\
\text { normalizer }\end{array}$ \\
\hline$E$ & Suspension & Oct 2002 & $\begin{array}{l}\text { Oct } \\
2005\end{array}$ & Nigeria & Yes & $\begin{array}{l}\text { Hibiscus sabdariffa, } \\
\text { Sorghum bicolor, } \\
\text { Gongronema } \\
\text { latifolium }\end{array}$ & $\begin{array}{l}\text { Immune } \\
\text { booster, } \\
\text { Energizer, } \\
\text { Blood } \\
\text { normalizer }\end{array}$ \\
\hline $\mathrm{F}$ & Solution & Aug 2004 & $\begin{array}{l}\text { Aug } \\
2006\end{array}$ & Nigeria & Yes & $\begin{array}{l}\text { Enantia chloranthia, } \\
\text { Mormodica } \\
\text { charanthia, } \\
\text { Citrus aurontifolia, } \\
\text { Morinda lucida, } \\
\text { Azaridachta indica, } \\
\text { Cocos nucifera, } \\
\text { Occimum } \\
\text { gratissimum, } \\
\text { Ananas comosus }\end{array}$ & Antimalarial. \\
\hline $\mathrm{G}$ & Solution & Oct 2004 & $\begin{array}{l}\text { Oct } \\
2006\end{array}$ & Nigeria & Yes & $\begin{array}{l}\text { Citrus aurantifolia, } \\
\text { Lawsonia inermis, } \\
\text { Azaridachta indica, } \\
\text { Morinda lucida, } \\
\text { Magnifea indica, } \\
\text { Ficus capensis, } \\
\text { Shonocentrum } \\
\text { jollyanum, } \\
\text { Theobroma cocao, } \\
\text { Nauclea latifolia }\end{array}$ & Antimalarial \\
\hline $\mathrm{H}$ & Solution & - & - & Nigeria & No & - & Antimalarial \\
\hline I & Solution & - & - & Nigeria & No & - & $\begin{array}{l}\text { Pruritis, } \\
\text { Rashes, skin } \\
\text { allergies. }\end{array}$ \\
\hline
\end{tabular}




\begin{tabular}{|c|c|c|c|c|c|c|c|}
\hline $\begin{array}{l}\text { Brand } \\
\text { code }\end{array}$ & $\begin{array}{l}\text { Dosage } \\
\text { form }\end{array}$ & $\begin{array}{l}\text { Date of } \\
\text { manufacture }\end{array}$ & $\begin{array}{l}\text { Expiry } \\
\text { Date }\end{array}$ & $\begin{array}{l}\text { Country of } \\
\text { Manufacrure }\end{array}$ & $\begin{array}{l}\text { NAFDAC } \\
\text { Registration }\end{array}$ & Contents & Therapeutic claim \\
\hline $\mathrm{J}$ & Solution & - & - & Nigeria & No & - & $\begin{array}{l}\text { Pile, dysentery, } \\
\text { other stomach } \\
\text { ailments }\end{array}$ \\
\hline K & Solution & - & - & Nigeria & No & - & $\begin{array}{l}\text { Eye ache, } \\
\text { Stomach ulcer, } \\
\text { waist pain, } \\
\text { menstrual pain. }\end{array}$ \\
\hline L & Solution & Jan 2004 & $\begin{array}{l}\text { Dec } \\
2006\end{array}$ & Nigeria & No & - & $\begin{array}{l}\text { Heamorrhoids, } \\
\text { pile. }\end{array}$ \\
\hline M & Solution & Sept 2004 & $\begin{array}{l}\text { Sept } \\
2007\end{array}$ & Nigeria & Yes & $\begin{array}{l}\text { Allum ascalonicum, } \\
\text { Strophanthus } \\
\text { hispidus, } \\
\text { Chrysophyllum } \\
\text { albidum,Nicotiana } \\
\text { rustica, Pseuphatil } \\
\text { kotscyi }\end{array}$ & $\begin{array}{l}\text { Gripe pain, } \\
\text { teething problem, } \\
\text { measles } \\
\text { management }\end{array}$ \\
\hline $\mathrm{N}$ & Solution & - & - & Nigeria & Yes & $\begin{array}{l}\text { Allium sativa, Xylopia } \\
\text { aromatica,Tetrapleura } \\
\text { tetraptera, } \\
\text { Ficus carica, } \\
\text { Nauclea latifolia, } \\
\text { Combretum } \\
\text { micrathum, Sterculia } \\
\text { ureus. }\end{array}$ & $\begin{array}{l}\text { Fever, measles, } \\
\text { skin rashes and } \\
\text { small pox. }\end{array}$ \\
\hline $\mathrm{O}$ & Solution & Aug 2004 & Jul 2007 & Nigeria & Yes & $\begin{array}{l}\text { Alstonia bonei, } \\
\text { Anthoderta nobilis, } \\
\text { Pandiaka involucrate, } \\
\text { Citrus medica, Var } \\
\text { acida, Phyllanthus } \\
\text { reticulates, Lawsonia } \\
\text { inermis, Ananaas } \\
\text { comosus, Gossypium } \\
\text { barbadense, } \\
\text { Azaridachta indica, } \\
\text { Zingiber officinale, } \\
\text { Shaenocentrum } \\
\text { jollyanum, } \\
\text { Sacharinum officinum }\end{array}$ & Antimalarial \\
\hline$P$ & Solution & Aug 2004 & $\begin{array}{l}\text { Aug } \\
2006\end{array}$ & Nigeria & Yes & $\begin{array}{l}\text { Xylopia aethopica, } \\
\text { Citrus medica, Var } \\
\text { acida, Cassia alata, } \\
\text { Kigella Africana bark, } \\
\text { Plerygota macrocana, } \\
\text { Sacchatrium officinum }\end{array}$ & $\begin{array}{l}\text { Menstrual } \\
\text { disorder, pain and } \\
\text { internal heat } \\
\text { during menses }\end{array}$ \\
\hline Q & Solution & Aug 2004 & $\begin{array}{l}\text { Aug } \\
2006\end{array}$ & Nigeria & Yes & 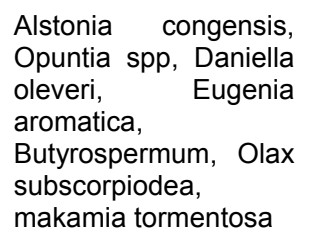 & $\begin{array}{l}\text { Eczema, body } \\
\text { rashes, } \\
\text { nettlerashes, } \\
\text { ringworm, acne. }\end{array}$ \\
\hline $\mathrm{R}$ & Powder & - & - & Nigeria & No & - & Heamorrhoids \\
\hline S & Powder & - & - & Nigeria & No & - & Typhoid fever \\
\hline $\mathrm{T}$ & Powder & - & - & Nigeria & No & - & Diabetes \\
\hline$U$ & Powder & - & - & Nigeria & No & - & Pile \\
\hline
\end{tabular}

- = Not stated/available 


\section{Determination of table/capsule properties:}

Twenty (20) tablets/capsules were weighed individually using an electronic balance (Mettler PE360 Deltarange, Switzerland) and the mean weight was calculated.

The crushing strength of the tablets was determined at room temperature using a Pfizer hardness tester (Pfizer Inc., Groton, CT). The mean crushing strength was calculated. The percent friability of the tablets was determined using a friabilator (Erweka Apparatebau ,Germany) operated at 25rpm for 4 min.

The disintegration times, DT, of the tablets/capsules were determined in distilled water at $37 \pm 0.5^{\circ} \mathrm{C}$ using an Erweka disintegration tester (Erweka Apparatebau ,Germany). All measurements were made in quadruplicate, and the results given are the means of four determinations.

\section{Determination of powder properties}

The particle size distribution and shape of the HMPs in powder dosage form were determined by optical microscopy on approximately 300 particles per sample.

The flow properties of the powders were evaluated by measuring the angle of repose. $5 \mathrm{~g}$ of each powder was poured into a cylindrical glass fixed to a flat base of diameter $28 \mathrm{~mm}$. The cylinder was slowly pulled out vertically so as to form a cone of powder on the base. The height of the cone was measured and the angle of repose, $\theta$, was calculated using the equation:

$\operatorname{Tan} \theta=h \backslash r$

where $\mathbf{h}$ is the height of the conical powder heap, and $r$ is the radius of the circular base. Determinations were done in triplicates.

\section{Determination of solutions properties}

The density of the solutions and suspension were determined by measuring the weight of $1 \mathrm{ml}$ of the sample. The density is taken as the mass per unit volume of the preparation.

\section{Phytochemical tests}

The following phytochemical tests were carried out on the products: Tests for alkaloids was performed using Wagner and Dragendoff's reagent $^{7} .0 .5 \mathrm{~g}$ of the product was added to $5 \mathrm{ml}$ of $1 \%$ aqueous $\mathrm{HC} 1$ on a steam bath. This was filtered and $1 \mathrm{ml}$ of the filtrate treated with a few drops of Draggendorf's reagent and another $1 \mathrm{ml}$ portion treated similarly with Wagner's reagent. The formation of precipitates was an indication of the presence of alkaloids. The blood heamolysis test was used to tests for Saponins ${ }^{7}$. The test for anthraquinone was done by shaking $0.5 \mathrm{~g}$ of the product with $5 \mathrm{ml}$ of chloroform for 5 min. The extract was filtered, and the filtrate shaken with an equal volume of $10 \%$ ammonia solution. A pink, violet or red colour in the ammoniacal layer (Lower layer) indicated the presence of free anthraquinones. The test for tannins was done using the ferric chloride test. A deep green colouration showed the presence of tannins ${ }^{8}$. The Keller- Kiliani test was used to test for the presence of cardenolides ${ }^{7,8} .0 .5 \mathrm{~g}$ of the product was dissolved in $2 \mathrm{ml}$ of glacial acetic acid containing one drop of ferric chloride solution. This was then underlayed with $1 \mathrm{ml}$ of concentrated sulphuric acid. A brown ring obtained at the interphase indicated the presence of a deoxy sugar typical of cardenolides $^{8}$.

\section{Microbial content determination:}

For solid samples i.e. tablets and powders, $1 \mathrm{~g}$ quantities were disintegrated in $9 \mathrm{~mL}$ of sterile distilled water while for the liquid formulations, $1 \mathrm{ml}$ quantities was dissolved/suspended in $9 \mathrm{ml}$ of sterile distilled water. Serial dilutions were made and viability assessed using the pour plate method. The plates were incubated at $37^{\circ} \mathrm{C}$ for $24 \mathrm{~h}$. The plate was placed on a colony counter and the number of colony forming units was taken. The microbial content was taken as the mean of duplicate determinations. The media utilized were Nutrient agar, Cetrimide Nutrient agar, Salt Nutrient agar, MacConkey agar. For detection of fungal growth in the samples, Sabouraud dextrose agar was poured into the plate and allowed to set and $1 \mathrm{ml}$ aliquot of each sample was spread on the surface and the plates were incubated at $27^{\circ} \mathrm{C}$ for $72 \mathrm{~h}$. 
Table 2: Physicochemical properties of the HMPs

\begin{tabular}{|c|c|c|c|c|c|c|c|c|c|}
\hline $\begin{array}{l}\text { Product } \\
\text { code }\end{array}$ & $\begin{array}{l}\text { Dosage } \\
\text { form }\end{array}$ & $\begin{array}{l}\text { Weight } \\
\text { uniformity } \\
\text { (mg) }\end{array}$ & $\begin{array}{l}\text { Crushing } \\
\text { Strength } \\
\text { (N) }\end{array}$ & $\begin{array}{l}\text { Friability } \\
(\%)\end{array}$ & $\begin{array}{l}\text { Disintegration } \\
\text { time (min) }\end{array}$ & $\begin{array}{l}\text { Weight } / \mathrm{ml} \\
(\mathrm{g} / \mathrm{ml})\end{array}$ & $\begin{array}{l}\text { Mean } \\
\text { particle size } \\
\mu \mathrm{m}\end{array}$ & $\begin{array}{l}\text { Angle } \\
\text { of } \\
\text { repose }\end{array}$ & $\begin{array}{l}\text { Bulk density } \\
\left(\mathrm{g} / \mathrm{cm}^{3}\right)\end{array}$ \\
\hline A & Tablet & $548.0 \pm 0.5$ & $137.2 \pm 19.6$ & $0.8 \pm 0.0$ & $120.0 \pm 3.0$ & - & - & - & - \\
\hline B & Capsule & $500.0 \pm 0.5$ & - & - & $30.0 \pm 4.5$ & - & - & - & - \\
\hline C & Capsule & $380.0 \pm 0.3$ & - & - & $39.0 \pm 2.5$ & - & - & - & - \\
\hline D & Capsule & $255.0 \pm 0.3$ & - & - & $54.0 \pm 4.0$ & - & - & - & - \\
\hline E & $\begin{array}{l}\text { Suspen } \\
\text { sion }\end{array}$ & - & - & - & - & $1.256 \pm 0.012$ & - & - & - \\
\hline $\mathbf{F}$ & Solution & - & - & - & - & $1.024 \pm 0.023$ & - & - & - \\
\hline G & Solution & - & - & - & - & $1.010 \pm 0.032$ & - & - & - \\
\hline H & Solution & - & - & - & - & $1.017 \pm 0.046$ & - & - & - \\
\hline I & Solution & - & - & - & - & $1.019 \pm 0.101$ & - & - & - \\
\hline J & Solution & - & - & - & - & $1.037 \pm 0.024$ & - & - & - \\
\hline K & Solution & - & - & - & - & $1.006 \pm 0.034$ & - & - & - \\
\hline $\mathbf{L}$ & Solution & - & - & - & - & $1.010 \pm 0.058$ & - & - & - \\
\hline M & Solution & - & - & - & - & $1.012 \pm 0.014$ & - & - & - \\
\hline $\mathbf{N}$ & Solution & - & - & - & - & $1.002 \pm 0.008$ & - & - & - \\
\hline 0 & Solution & - & - & - & - & $1.039 \pm 0.012$ & - & - & - \\
\hline $\mathbf{P}$ & Solution & - & - & - & - & $0.990 \pm 0.009$ & - & - & - \\
\hline Q & Solution & - & - & - & - & $1.037 \pm 0.056$ & - & - & - \\
\hline $\mathbf{R}$ & Powder & - & - & - & - & - & $215.56 \pm 5.90$ & $52.6 \pm 1.2$ & $0.232 \pm 0.002$ \\
\hline s & Powder & - & - & - & - & - & $2.87 \pm 0.98$ & $61.9 \pm 2.6$ & $0.427 \pm 0.026$ \\
\hline $\mathbf{T}$ & Powder & - & - & - & - & - & $98.70 \pm 2.67$ & $60.0 \pm 0.9$ & $0.368 \pm 0.042$ \\
\hline u & Powder & - & - & - & - & - & $13.38 \pm 1.12$ & $66.5 \pm 1.8$ & $0.386 \pm 0.008$ \\
\hline
\end{tabular}

The viable aerobic bacterial count and the viable count for moulds (dry surface method) and the absence (or presence) of Escherichia coli and Staphylococcus aureus were assessed using well established methods ${ }^{9,10}$.

\section{Results and discussion}

The herbal medicinal products selected for this study consisted of one (1) tablet, one (1) suspension, three (3) capsule, four (4) powders and twelve (12) liquid dosage forms. All the samples, except for those samples without the manufacture or expiry dates indicated, were within their shelf life at the time of investigation. Twelve $(57.1 \%)$ of the products had their manufacturing and expiry dates stated and only nine $(42.9 \%)$ products have been registered by NAFDAC. This is contrary to the prohibition of the manufacture, advertisement, sale and distribution of herbal medicinal products in
Nigeria without proper registration by NAFDAC ${ }^{11}$. The European Agency for the Evaluation of Medicinal Products, EMEA and $\mathrm{WHO}$ have stated that the quantity of the herbal drug should be given as a range corresponding to a defined quantity of constituent with known therapeutic activity and if constituent(s) responsible for the therapeutic activity are unknown, the quantity of the whole herbal drug preparation should be given ${ }^{6,12}$. Furthermore, the dosage form, therapeutic indications and expiry dates should be stated. However, ten $(47.6 \%)$ of the products did not have their content stated even though their therapeutic claims were indicated either on the container or in the leaflet insert.

The physicochemical properties of the product formulations are presented in Table 2. The European Pharmacopoeia have stated that 
Table 3: Phytochemical analysis of the HMPs

\begin{tabular}{|c|c|c|c|c|c|}
\hline \multirow{2}{*}{ Product code } & \multicolumn{5}{|c|}{ Phytochemical tests } \\
\hline & Alkaloids & Anthraquinones & Saponins & Tannins & cardenolides \\
\hline A & + & - & - & + & - \\
\hline B & - & + & + & + & + \\
\hline C & + & - & + & + & - \\
\hline D & - & - & + & - & - \\
\hline E & + & - & + & - & - \\
\hline $\mathbf{F}$ & - & - & + & + & + \\
\hline G & - & - & + & + & - \\
\hline $\mathbf{H}$ & - & - & + & + & - \\
\hline \multicolumn{6}{|l|}{ I } \\
\hline J & - & + & - & - & - \\
\hline K & + & - & - & - & - \\
\hline $\mathbf{L}$ & + & - & - & - & - \\
\hline M & - & - & + & + & - \\
\hline $\mathbf{N}$ & - & - & + & + & + \\
\hline 0 & - & - & + & - & - \\
\hline $\mathbf{P}$ & - & - & + & - & + \\
\hline $\mathbf{Q}$ & - & - & + & - & + \\
\hline $\mathbf{R}$ & + & - & - & + & - \\
\hline s & - & - & + & + & - \\
\hline $\mathbf{T}$ & + & - & + & + & + \\
\hline $\mathbf{U}$ & + & + & + & + & - \\
\hline Key: & $\begin{array}{l}- \\
+\end{array}$ & $\begin{array}{l}\text { Absent } \\
\text { Present }\end{array}$ & & & \\
\hline
\end{tabular}

tablets $\geq 250 \mathrm{mg}$ may not deviate from the average weight by more than $5 \% \mathrm{w} / \mathrm{w}$ and capsules of $\geq 300 \mathrm{mg}$ may not deviate by more than $7.5 \% \mathrm{w} / \mathrm{w}^{13}$. The results of the weight uniformity test for the tablets and capsules were within the acceptable pharmacopoeial limits. The tablet formulation (Product A) showed acceptable crushing strength and friability indicating the ability to resist chipping and abrasion or breakage under conditions of storage, transport and handling. However, the tablet had disintegration time of $120 \mathrm{~min}$. This is considerably higher than the requirement for immediate release tablets (i.e. disintegration within 15minutes). This may result in delayed release of the active constituent and subsequent onset of action. In many cases, a complete and rapid disintegration/dissolution of the herbal drug preparation for example extracts, from the solid oral dosage formulation is a prerequisite for non- problematic bioavailability and clinical efficacy of the HMPs. Some preparations such as lipid extracts and essential oils however are not easily soluble and do not dissolve completely from the pharmaceutical formulation ${ }^{6}$. Such HMPs may require other excipients such as disintegrants to aid the release of the active constituent from the dosage form. The disintegration times of the capsules (Products B - D) also varied considerably. Products $C$ and $D$ did not pass the pharmacopoeial test for disintegration of capsules (i.e. disintegration within 30minutes). The weight per $\mathrm{mL}$ of the solution was used as a means of assessing the uniformity of weight per dose of the product dispensed. The solutions (Products F - Q) generally contained about $1 \mathrm{~g}$ per $\mathrm{mL}$ of the solution and the standard deviation showed that the variation in weight was generally $\leq 5 \%$. The angle of repose of the powders (Products $R-U$ ) 
Table 4: Microbial content of HMPs

\begin{tabular}{|c|c|c|c|c|c|c|}
\hline \multirow{2}{*}{$\begin{array}{l}\text { Product } \\
\text { code }\end{array}$} & \multicolumn{6}{|c|}{ Viable count (cfu/ml or g) } \\
\hline & $\begin{array}{c}\text { Aerobic } \\
\text { organisms }\end{array}$ & $\begin{array}{c}\text { Staph. } \\
\text { auereus }\end{array}$ & E.coli & Salmonella & Pseudmonads & Fungi \\
\hline A & - & - & - & - & - & $4.0 \times 10^{3}$ \\
\hline B & $5.0 \times 10^{3}$ & $1.4 \times 10^{4}$ & $7.0 \times 10^{3}$ & - & - & - \\
\hline C & $7.5 \times 10^{3}$ & $2.0 \times 10^{3}$ & $3.0 \times 10^{3}$ & - & - & - \\
\hline D & $3.0 \times 10^{4}$ & $7.0 \times 10^{3}$ & $13.0 \times 10^{3}$ & $3.0 \times 10^{3}$ & - & - \\
\hline E & $2.0 \times 10^{4}$ & $3.0 \times 10^{4}$ & $7.0 \times 10^{3}$ & $1.0 \times 10^{3}$ & - & $3.0 \times 10^{4}$ \\
\hline $\mathbf{F}$ & $1.0 \times 10^{3}$ & $1.0 \times 10^{3}$ & - & - & - & - \\
\hline G & $5.0 \times 10^{2}$ & - & - & - & - & - \\
\hline H & $5.0 \times 10^{3}$ & $1.0 \times 10^{3}$ & - & - & - & - \\
\hline $\mathbf{I}$ & $5.0 \times 10^{3}$ & $2.0 \times 10^{3}$ & $1.5 \times 10^{2}$ & $1.0 \times 10^{3}$ & - & $2.0 \times 10^{3}$ \\
\hline J & $1.5 \times 10^{2}$ & $5.0 \times 10^{2}$ & - & - & - & - \\
\hline K & $7.5 \times 10^{3}$ & $1.0 \times 10^{3}$ & - & - & - & - \\
\hline $\mathbf{L}$ & $5.0 \times 10^{3}$ & - & - & - & - & - \\
\hline M & - & - & - & - & - & $3.0 \times 10^{3}$ \\
\hline $\mathbf{N}$ & $2.0 \times 10^{4}$ & $4.0 \times 10^{3}$ & $1.5 \times 10^{4}$ & - & - & $1.2 \times 10^{4}$ \\
\hline 0 & - & - & - & - & - & $3.5 \times 10^{3}$ \\
\hline $\mathbf{P}$ & - & - & - & - & - & $3.0 \times 10^{3}$ \\
\hline Q & $1.0 \times 10^{4}$ & $5.0 \times 10^{3}$ & - & - & - & $3.5 \times 10^{3}$ \\
\hline $\mathbf{R}$ & $2.2 \times 10^{4}$ & $1.2 \times 10^{4}$ & $9.0 \times 10^{3}$ & $3.0 \times 10^{2}$ & - & $1.2 \times 10^{4}$ \\
\hline s & $8.0 \times 10^{3}$ & $6.0 \times 10^{3}$ & $5.0 \times 10^{3}$ & $2.0 \times 10^{2}$ & - & $7.0 \times 10^{3}$ \\
\hline$T$ & $5.0 \times 10^{3}$ & $3.0 \times 10^{3}$ & $2.0 \times 10^{3}$ & $1.5 \times 10^{2}$ & - & $6.0 \times 10^{3}$ \\
\hline u & $8.0 \times 10^{3}$ & $2.0 \times 10^{3}$ & $3.0 \times 10^{3}$ & $2.0 \times 10^{2}$ & - & $3.5 \times 10^{3}$ \\
\hline
\end{tabular}

Key: $\quad$ - = No growth

$\mathrm{Cfu} / \mathrm{ml}=$ Colony forming unit per $\mathrm{ml}$ or $\mathrm{g}$

was generally high showing that the powders were highly cohesive and are not free-flowing. This may result in the non-uniformity of dose dispensed from the container during use.

In contrast to orthodox medicinal products, the compositions of herbal drug preparations are determined by the practitioner, manufacturing process, and the intended dosage form herbal drug $^{6}$. The results of the phytochemical tests are presented in Table 3. The results showed that the products contain alkaloids, anthraquinones, tannins, saponins and cardinolides. It is well known that HMPs usually consists of more than one plant or active constituents and their therapeutic efficacy is not provided by a single group of compounds. Some of these compounds act synergistically to modify the bioavailability and efficacy of the active constituent. Furthermore, the constituent responsible for the claimed therapeutic effects are often unknown or only partly explained and thus precludes the level of control which could be routinely achieved with synthetic drug substances in conventional pharmaceuticals ${ }^{6}$. Moreover, the composition of an herbal drug preparation is determined by the practitioner who should be able to identify the correct plant species. Thus, misidentification of the plant is possible and the plants may contain potentially toxic constituents. As a result, there is 
no guarantee of the authenticity and quantity of plant material used in the preparations and thus the quality of traditional medicines so produced varies widely and may not even be effective. Furthermore, herbal medicines, particularly those grown as cultivated crops have been shown to be contaminated by pesticides, fumigants, toxic metals and endotoxins ${ }^{13}$. Therefore, there is a need to select proper and appropriate technologies for the industrial production of traditional medicines such that the effectiveness of the preparation is ensured.

Herbal medicinal products usually contain bacteria and moulds from soil and atmosphere. The limits of microbial contamination are: total aerobic bacteria $10^{5} \mathrm{cfu} / \mathrm{g}$, yeasts and moulds $10^{3}$ $\mathrm{cfu} / \mathrm{g}$, Enterobacteria and other Gram negative organisms $10^{3} \mathrm{cfu} / \mathrm{g}$ and $\mathrm{E}$. coli and Salmonella should be absent ${ }^{14}$. The microbial nature and content of the microbial contaminant in the HMPs are presented in Table 4. The results show that the microbial load of the products varied considerably. The samples were contaminated to varying degrees with bacteria and Fungi. Of concern is the level of contamination of the products by Gram negative organisms which are considered pathogenic. While none of the samples contained Pseudomonas aeruginosa, which is primarily a soil bacterium and the cause of various infections, e.g. of burns, and the urinary and respiratory tracts, ten $(47.6 \%)$ of the samples were contaminated by E.coli, which is an intestinal bacterium and is an indicator for contamination by feaces and seven (33\%) were contaminated with Salmonella. Fifteen (71.4\%) of the products were contaminated by Staphylococcus aureus and twelve $(57.1 \%)$ were contaminated by fungi. Soil, harvesting, drying, storage conditions and improper handling influence the microbiological quality of herbal drugs. The presence of microbial contaminant in non sterile pharmaceutical products can reduce or even inactivate the therapeutic activity of the products and has the potential to adversely affect patients taking the medicines ${ }^{15}$. Some infectious outbreaks have been associated with the use of heavily contaminated raw materials of natural origin ${ }^{16}$. The microbial quality of pharmaceuticals is influenced by the environment and quality of the raw materials used during formulation. Thus manufacturers should ensure the lowest possible level of microorganisms in the raw material, finished dosage forms and the packaging components to maintain appropriate quality, safety and efficacy of the products.

The results of the present work show that Products $A$ to $D$, which were among the products which did not show acceptable pharmaceutical and microbial qualities were expensive, popular, widely advertised and used in south western Nigeria for the treatment of various conditions. There is, therefore, the need for constant monitoring and quality control of herbal medicinal products manufactured, sold, advertised and used in Nigeria. The quality requirements for orthodox drug preparations are stringent in terms of content of active principles and toxic materials. Whereas the production of traditional medicines for local use does not require such stringent standards, HMPs are usually an improved version of the already produced medicines using traditional methods. As herbal medicinal products are complex mixtures which originate from biological sources, great efforts are necessary to guarantee a constant and adequate quality. By carefully selecting the plant material and a standardized manufacturing process, the pattern and concentration of constituents of herbal medicinal products should be kept as constant as possible as this is a prerequisite for reproducible therapeutic results ${ }^{6}$. Quality has to be built into the whole process beginning from the selection of propagation material to the final product reaching the consumer. Thus, there is need for constant monitoring and control of the standards of herbal medicines available in the market.

\section{REFERENCES}

1. Eisenberg DM, Davis RB, Ettner SL, Appel S, Wilkey S, Van Rompay M, Kessler RC Trends in alternative medicine use in the United States, 1990-1997: Results of a follow-up national survey. J. Amer. Med. Assoc. 1998; 280: 1569-1575. 
2. Akerele, O. Nature's medicinal bounty: don't throw it away. World Health Forum. 1993; 14: 390-395.

3. WHO, Regulatory situation of herbal medicine: A world wide review. World Health Organization, Geneva. 1998.

4. WHO, General guidelines for methodologies on research and evaluation of traditional medicines. World Health Organization, Geneva. 2000.

5. Lau A, Holmes MJ, Woo $\mathrm{S}$ and Koh $\mathrm{H}$. Analysis of adulterants in a traditional herbal medicinal product using liquid chromatography-mass spectroscopy. J. Pharm. Bio. Ana. 2003; 31: 401-406.

6. The European Agency for the Evaluation of Medicinal Products, EMEA Working Party on Herbal Medicinal Products: Points to consider on the biopharmaceutical characterization of Herbal Medicinal Products. EMEA/HMPWP/344/03 (2003) http://www.emea.eu.int/pdfs/human/hmpc/034403e n.pdf Last accessed on October 10, 2006.

7. Sofowora, E.A. Medical Plant and Traditional Medicine in Africa. University of Ife Press, Nigeria: 1994; pp. $1-23$.

8. Evans WC: Trease and Evans Pharmacognosy. 14th edition. WB Saunders Ltd. London; 1996; pp.119159.

9. Van Doorne $\mathrm{H}$. and Claushauis EPM. The quantitative determination of Enterobacteriaceae in pharmaceutical preparations. Int. J. Pharm. 1979; 4: $119-125$.
10. Waterman RF, Sumner ED, Baldwin JN and Warren FW. Survival of Staphylococcus aureus on pharmaceutical oral solid dosage forms. J. Pharm. Sci. 1973; 62: 1317 - 1320.

11. Herbal Medicines and Related Products (Registration) Regulations (2004) www.nafdacnigeria.org/newregs/regulations.html Last accessed on October 10, 2006

12. WHO Expert Committee on Specifications for Pharmaceutical Preparations. Thirty-fourth report. Geneva, World Health Organization, 1996 (WHO Technical Report Series No. 863, thirty-fourth report, pp.178-184).

13. Chan K. Some aspects of toxic contaminants in herbal medicines. Chemosphore 2003; 52; 1361-1371.

14. European Pharmacopoeia: Directorate for the Quality of Medicines of the Council of Europe, $5^{\text {th }}$ Edition. Strasbourg, France. (2007)

15. Nakajima K, Nonaka K, Yamamoto K, Yamaguchi N, Tani K and Nasu M Rapid monitoring of microbial contamination on herbal medicines by fluorescent staining method. Lett. Applied Microbiol. 2005; 40 (2): 128-132

16. Kallings LO, Silver Stolpe $L$ and Ernerfeldt $F$. Microbiological contamination of medical preparations. Act. Pharm. Suec. 1966; 3: 219 228. 